Millatī, Journal of Islamic Studies and Humanities

Vol. 4, No. 2, Desember 2019: p. 208-227. DOI: 10.18326/mlt.v4i2. 208-227

p-ISSN : 2541-3627; e-ISSN 2540-9964

Website: http://millati.iainsalatiga.ac.id/index.php/millati/index

\title{
Arguments of Hadith for Tolerance
}

\author{
Ismail Fahmi Arrauf Nasution
}

IAIN Langsa, Indonesia

ismailfahmiarraufnasution@iainlangsa.ac.id

Miswari
LAIN Langsa, Indonesia
miswari@iainlangsa.ac.id

\begin{abstract}
:
This article has two tasks; First, exploring the hadith which is the basis of Islamic arguments for religious tolerance; The second builds the hadith argument for tolerance. Researchers found in the popular hadith codification such as Shabih Bukhari and Shabih Muslim, explicitly difficult to find hadith tolerance. This problem is the basis of the building arguments for the perception that Islam does not teach tolerance, Islam is not a tolerant religion. Researchers find tolerance hadiths in popular codification more than the themes of mu'amalab and social relations. Tolerance hadiths are very much found in the theme of the faith. From tolerance traditions found to be able to roast the perception of Islam is not a tolerant religion. Researchers build Islamic arguments for tolerance based on tolerance traditions that have been collected. Researchers found that Islam is a religion that is peaceful and puts forward tolerant attitudes in religion and social life. Islam as other religions is present as a religion that calls for good and forbids from bad attitudes and actions. Bad attitudes and actions arise from the selfhood of humans who come out of fitrah.
\end{abstract}

Keywords: hadith, tolerance, Islam, goodness and evil, religion

\begin{abstract}
Abstrak
Artikel ini memiliki dua tugas; Pertama mengeksplorasi hadits yang menjadi basis argumentasi Islam untuk toleransi beragama; Kedua membangun argumentasi hadits untuk toleransi. Peneliti menemukan dalam kodifikasi hadits popular seperti Shahih Bukhari, Shahih Muslim, secara eksplisit sulit ditemukan hadits toleransi. Masalah ini menjadi basis argumentasi bangunan persepsi bahwa Islam tidak mengajarkan toleransi, Islam bukan agama toleran. Peneliti menemukan hadits-hadist toleransi dalam kodifikasi popular lebih banyak berada di luar tema muamalah dan hubungan sosial. Hadits-hadits toleransi sangat banyak ditemukan dalam tema keimanan. Dari hadits-hadits toleransi yang ditemukan dapat menyangga persepsi Islam bukan agama toleran. Peneliti membangun argumentasi Islam untuk toleransi berdasarkan hadits-hadits toleransi yang berhasil dihimpun. Peneliti menemukan bahwa Islam adalah agama yang damai dan mengedepankan sikap-sikap toleran dalam beragama dan dalam berkehidupan sosial. Islam sebagaimana agama-agama lainnya hadir sebagai agama yang menyeru kepada kebaikan dan melarang dari sikap dan perbuatan buruk. Sikap dan perbuatan buruk muncul dari kedirian manusia yang keluar dari fitrah.
\end{abstract}

Kata Kunci: hadits, toleransi, Islam, kebaikan dan keburukan, agama 


\section{INTRODUCTION}

Tolerance in Islam is a very important discussion to study. The reason, Muslims generally understand the meaning of tolerance erroneously. The term "tolerance" is also usually used recklessly as an Islamic argument for pluralism. But secularism is misunderstood so it reaps a lot of opposition. It is even more ironic when a mistaken understanding of the meaning of tolerance is used as an argument to support the existence of streams that have the potential to cause social conflict.

Lack of understanding due to the lack of scientific discourse about the roots of tolerance in Islam, especially those based on the hadith causes people to be very intolerant. Even the heretical claims and accusations of the Christianization program are due to reactionary attitudes with no argument in Islam that orders to do good to non-Muslims. This claim makes the reactionaries deny with a reactionary attitude and is easily suspicious of creating peace and harmony between religious communities. It is the Islamic creed that will be sacrificed because these reactionary claims that it does not have solid arguments in Islam.

The low awareness of tolerance in Muslim societies occurs due to the claim that Islam does not have a clear source for ordering tolerance to be reviewed. The author finds, in the codifications of popular hadith, such as Sahih Bukhari, Sahih Muslim, Sunan Abu Dawud, Riyadush Shalihin ${ }^{1}$, and other hadith codifications, the command to be tolerant is indeed not found explicitly. In the Qur'an, the theme of tolerance is also difficult to find. There are several possibilities for this scarcity. Among them as stated by Gama in his research that the focus of the Qur'an is divinity, afterlife, a treatise of religion, faith, shirk kufr, and others ${ }^{2}$ so that the parts that become social themes, especially regarding tolerance between religious communities, are not getting much attention in nash.

One aspect of Islamic teachings that are currently receiving much attention is the concept of tolerance. Today's claim to Islam is a religion that is anti-tolerance and pluralism. Many opinions develop that Islam and Muslims do not value equality of life and human rights. This assumption occurs systematically and sustainably.

\footnotetext{
${ }^{1}$ Imam An-Nawawi, Terjemah Lengkap Riyadish Shalibin, (Surakarta: Ziyad Books, 2017).

${ }^{2}$ Cipta Bakti Gama, "Fondasi Psikopatologi Islam: Suatu Pendekatan Psikofilosofis tentang Konsep Gangguan Jiwa dan Faktor Penyebabnya dalam Alquran”, Dissertation, PTIQ Jakarta, 2018, p. 217-218.
} 
Millatī, Journal of Islamic Studies and Humanities, Vol. 4, No. 2, Desember 2019: 208-227

This article aims to explore the arguments in the text about tolerance, especially in the hadith. This study is important because today the problem of intolerance has become the image of Islam so that Islam is recognized as an intolerant religion. The significance of this study is to show that Islam has a basis for tolerance so that it can correct the assumption of the absence of an argument in Islam to be tolerant and show that Islam is a religion tolerant.

To anticipate the negative impacts that are worrying, of course, it is very necessary to try to re-explore and live the Islamic concept of vague tolerance. In this framework, borrowing the term Yusuf Qaradhawi, it is intended to explain the true concept (taudîh al-haqâiq), dispel doubts(izâlah as-subuhât), and correct wrong perceptions (tashîh al-afhâm). ${ }^{3}$

Tolerance is a scientific discussion that has captured the attention of Islamic scientists for a long time. Among the scholars' studies on this subject is al-Khilal's work entitled "Hukum Toleransi antar Agama" and Ibn Qayyim's work entitled "Hukum Abli Zimmab". Today, there are also several studies on tolerance such as Agung Setiyawan's study which is oriented as an educational theme ${ }^{4}$. Salamah Noorhidayati also analyzes tolerance with a focus on relationships between religious communities ${ }^{5}$. Tracking the basis of tolerance is generally done by tracking the foundation of tolerance of the Quran and hadith as done by Cici Kusnadi ${ }^{6}$. This article wants to examine tolerance based on hadith studies.

\section{DISCUSSION}

\section{Definition of Tolerance}

In the Indonesian Dictionary, the word tolerance means the nature or attitude of tolerance. ${ }^{7}$

The word tolerant itself is defined as being tolerant (respecting, allowing, allowing) the stance (opinions, views, beliefs, habits, behavior, etc.) that are different or contrary to his own opinion. ${ }^{8}$

${ }^{3}$ Yusuf al-Qaradhawi..Fatâwâ Mu'âshirah. $3^{\text {rd }}$ printing., vol. 2 (Mansurah: Dar al-Wafa'. 1994), p. 667.

${ }^{4}$ Agung Setiyawan, "Pendidikan Toleransi Dalam Hadits Nabi Saw", Jurnal Pendidikan Agama Islam, Vol. XII, No. 2, p. 2015.

5Salamah Noorhidayati, "Hubungan Antar Umat Beragama Dalam Perpektif Hadits", Kalam, Vol. 10, No. 2, December 2016.

${ }^{6}$ Cici Kusnadi, "Kajian Al-Qur'an Dan Sunnah Tentang Toleransi”, Al-Karimah Jurnal Ilmiah Ilmu Tarbiyah Dan Ekonomi Syariah, Vol. 04 No. 07, 2017.

${ }^{7}$ Ministry of Education and Culture of the Republic of Indonesia. 1991. Kamus Besar Bahasa Indonesia. $2^{\text {nd }}$ Printing., Jakarta: Balai Pustaka), p.1065.

${ }^{8}$ Ibid. 
The word toleransi is not actually "authentic" Indonesian language, but the absorption of English word which is tolerance. According to the Oxford Advanced Learners Dictionary of Current English, tolerance is the quality of tolerating opinions, beliefs, customs, behaviors, etc., different from one's own. ${ }^{9}$ Furthermore, according to Abdul Malik Salman, the word tolerance itself comes from the Latin language that is tolerare which means trying to stay alive, live, or interact with something that is not liked or liked. ${ }^{10}$ Thus, initially in the sense of tolerance contained an attitude of compulsion.

In Arabic, the term commonly used as an equivalent of the word tolerance is samâhah or tasâmuh. This word means al-jûd (glory),11 or sa'at al-sadr (relieved) dan tasâhul (friendly and forgiving).12 This meaning then developed into an open attitude (welcome) in dealing with differences that originate from noble personalities.13 Thus, it is different from the word tolerance which contains nuances of compulsion so, the word tasâmuh has virtue because it symbolizes the attitude that comes from self-glory (al-jûd wa al-karam) and sincerity.

While the word tasâmuh in al-Qamus al-Muhit, is a derivation of the word "samh" which means "jud wa karam wa tasâhul" (generous and helpful attitude). In the book Mu'jam Maqâyis al-Lughah by Ibnu Faris, the word samâhah is translated as subulah (simplify). This understanding is also reinforced by the words of Ibn Hajar al-Asqalani in Fath al-Bâri which says that as-sambah with the word as-sablab (easy), in interpreting a history that reads Ababbu ad-din ila Allahb al-hanifiyyah as-sambah. This difference in meaning certainly influences the understanding of the use of these words in both languages (Arab-Inggris).

An understanding of tolerance cannot stand alone. This is closely related to another reality in nature which is a direct cause of the birth of tolerance. Both are like two sides of an inseparable coin. Understanding tolerance is meaningless without understanding this other reality, namely pluralism (pluralism; Arabic: ta'addudiyyab). Thus, to be able to tolerate well, the understanding of pluralism in advance is necessary.

${ }^{9}$ A. S. Hornby. Oxford Advanced Learners Dictionary of Current English. 23rd Printing (London: Oxford University Press, 1986.). p.909.

${ }^{10}$ Abdul Malik Salman,al-Tasâmub Tijâh al-Aqaliyyât ka Darûratin li al-Nabdah. (Kairo: The International Institute of Islamic Thought), p.2.

${ }^{11}$ Jamaluddin Muhammad bin Mukram Ibn al-Mandzur. t.th. Lisân al-'Arab, 1 ${ }^{\text {st }}$ Printing. Vol. 7 (Beirut: Dar Shadir., 1993), p.249.

${ }^{12}$ Ahmad Warson Munawwir.. Kamus al-Munawwir Arab Indonesia Terlengkap, 2 ${ }^{\text {nd }}$ Edition. 14 ${ }^{\text {th }}$ Printing (Surabaya: Pustaka Progresif1997), p. 657

${ }^{13}$ Salman.al-Tasâmub Tijâh, p.2. 
Millatī, Journal of Islamic Studies and Humanities, Vol. 4, No. 2, Desember 2019: 208-227

In reviewing traditions about tolerance, it is referred to the original meaning of the word samâhah in Arabic (which means to facilitate, to give generosity and breadth) and not to refer to the meaning of the word tolerance in English which means to hold feelings without protest. However, the meaning makes it easy and giving breadth here is not absolute as freely understood, but it still uses the Qur'anic and Hadith benchmarks.

Al-banifiyyah as-sambah as stipulated in the Prophet's hadith: ababbu ad-din ila Allâh alhanifiyyah as-sambah (the most beloved religion in the sight of Allah is al-hanifiyyah al-sambah: a religion that is oriented to the spirit to seek truth in a manner tolerant and roomy). Here, the meaning of as-sambah, contains linguistic affinity with tasâmub or samâha: a modern Arabic terminology to refer to tolerance. The Prophet's hadith is often used as a reference for Islam to support tolerance of other religions.

The Qur'an never mentions the word tasâmuh or tolerance explicitly so that we will never find the word contained in it. However, the Qur'an explicitly explains the concept of tolerance with all its limitations clearly and clearly ${ }^{14}$. Therefore, the verses that explain the concept of tolerance can be used as a reference in the implementation of tolerance in life.

As for the hadith literature, the word tolerance is popularly used with the word tasâmuh which comes from the word samuha-yasmuhu-samhan wa simâhan wa samahatan. Several times the Messenger of Allah. using the word variant to direct the message to tolerance, God willing, we can find it in the following discussion. Therefore, the traditions that explain the concept of tolerance can be used as a reference in the implementation of tolerance in life.

\section{Tolerance in Hadith}

In one of the hadiths, the Prophet said:

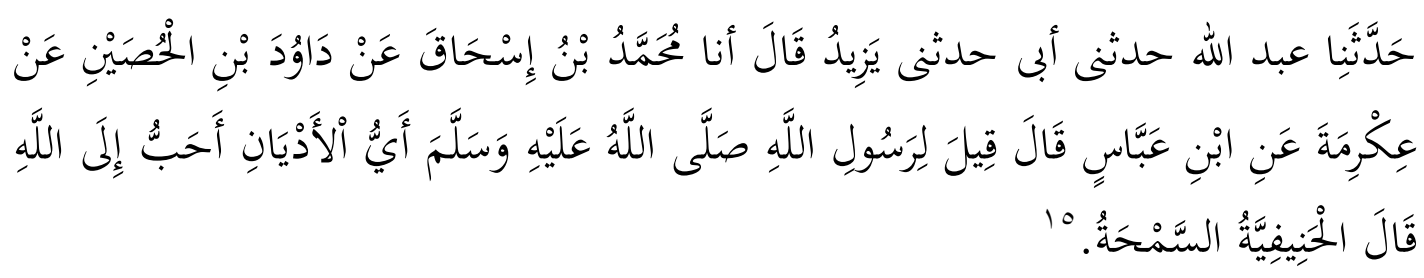

"For telling us Abdillah, for telling me Abi, for telling me Yazid said; has preached to us Muhammad bin Ishaq from Dawud bin Al Hosain from Ikrimah from Ibn

\footnotetext{
${ }^{14}$ Ismail Fahmi Arrauf Nasution, Melarai Titik Tengkar Agama: Teologi Dialog Antaragama dalam Alquran, (Langsa: Zawiyah, 2018), p.74.

${ }^{15}$ Ibid., p. 236
} 
Abbas, he said, asked the Messenger of Allah which religion is most loved by God? then he said, Al Hanifiyyah As Samhah (the straight and tolerant)"

According to Ibn Hajar al-Asqalany, this hadith was narrated by Al-Bukhari in the book of Faith "Religion is easy" in its validity mu'allaq by not mentioning its sanad because it is not included in the category of valid hadith terms according to Imam al-Bukhari, will but he mentions his sanad in full in al-Adab al-Mufrad which is narrated from the friend of Abdullah bin 'Abbas with a warm sanad. ${ }^{16}$ While Sheikh Nashiruddin al-Albani said that this hadith is a hadith whose position is hasan lighairih." 17

Based on the above hadith, it can be said that Islam is a religion that is tolerant in various aspects of religion both in terms of aqeedah and sharia and is focused on muamalah region. The Prophet Muhammad said:

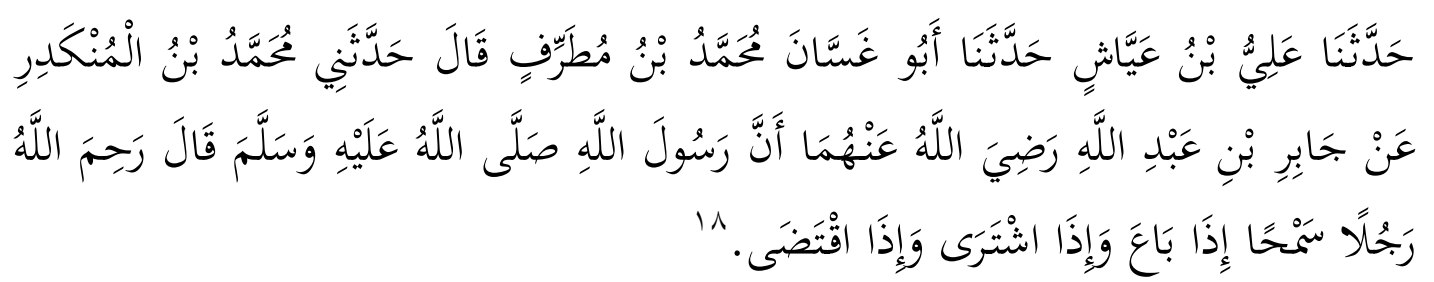

"For telling us Ali bin Ayyasy, telling us Abu Ghassan Muhammad bin Mutarrif saud, Muhammad bin Al Munkadir from Jabir bin Abdullah has told me that the Messenger of Allah said that Allah blessed the people who made it easy when selling and when buying and also people who ask for their rights."

Al-Bukhari gives chapters to the word as-Samâhah (tolerant) in this hadith with the word ease, He said, ease and tolerance in buying and selling. for tolerance in social interactions and using noble character and noble mind by abandoning stinginess towards oneself. Also, this hadith recommends not to make it difficult for humans to take away their rights and receive forgiveness from them. ${ }^{19}$

Islam since its arrival, standing on the principle of convenience, the Prophet Muhammad said:

\footnotetext{
${ }^{16}$ Ahmad bin Ali bin Hajar al-'Asqalany, Fath al-Barî, vol. I, (Madinah al-Munawarah, 1996), p. 94.

${ }^{17}$ Muhammad Nasiruddin al-Albany, Shahih adab al-Mufrad 2nd Printing. (Beirut: Dar ash-Shiddiq, 1415 H), p.122.

${ }^{18}$ al-Bukharî, "Bab Buyu"' Sabih al-Bukharî, p.133

${ }^{19}$ Ali bin Hajar, vol. IV,Fath al-Barî, p.207
} 


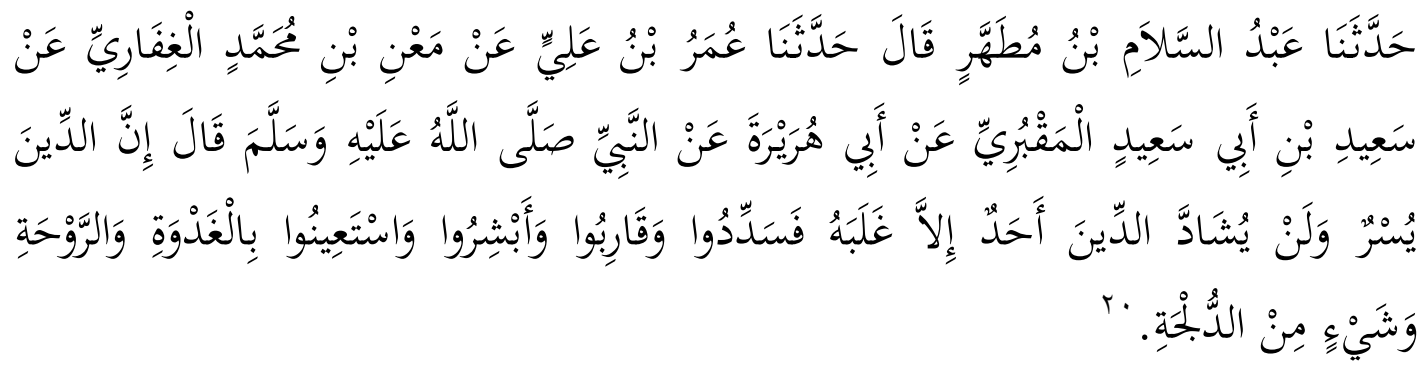

"For telling us Abdus Salam ibn Mutahhar said, telling us Umar bin Ali from Ma'an bin Muhammad Al Ghifari from Sa'id bin Abu Sa'id Al Maqburi from Abu Hurairah that the Prophet sallallaahu 'alaihi wasallam said: "Verily the religion it's easy, and not someone complicates religion unless he will be defeated (heavier and more difficult), then act straight, come closer (to the right) and give good news and ask for help with $\mathrm{Al}$ Ghadwah (departing early in the morning) and ar-ruhah (departing after Dhuhr) and something from ad-duljah ((departing at night) "

Ibn Hajar al-'Asqalânî said that the meaning of this hadith is the prohibition of being tasyaddud (harsh) in religion that is when someone forces himself to do worship while he is unable to carry it out that is the intention of "And absolutely no one applies harshly in religion unless defeated" . Religion is not carried out in the form of coercion. Whoever imposes or acts violently in religion, religion will defeat it and stop its actions. ${ }^{21}$

In another narration it is stated that once the Prophet Muhammad came to 'Aisha at that time there was a woman with` Aisha. The woman told the Prophet. regarding the prayer then the Messenger of Allah. said:

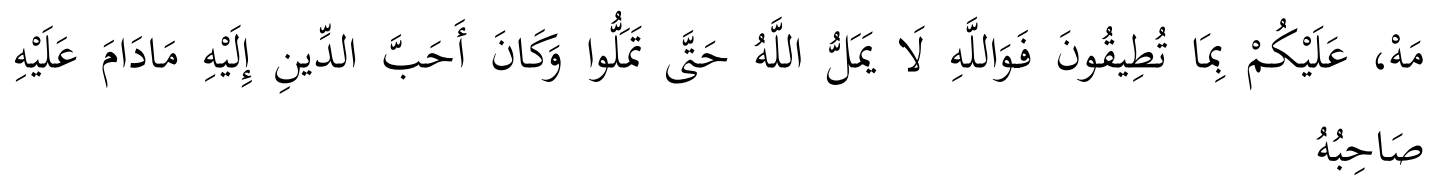

"Stop it, do what you are able to do, and for the sake of Allah truly Allah is not bored until you are bored, and the Religion most loved by Him is what is consistently carried out by its adherents." 22

\footnotetext{
${ }^{20}$ Imam Abi Abdillah Muhammad bin Ismail bin Ibrahim ibn al-Mughirah bin Bardazibah al-Bukhariy alJu'fiy, Shabih al-Bukhari, Juz 1, (Semarang: Maktabah wa Matba'ah Usaha Keluarga, 1981), p.15.

${ }^{21} \mathrm{Al}-‘$ Asqalany, Op.Cit., Vol. I, p. 143

${ }^{22}$ Al-Bukhari, Op.Cit., Jld. I, h. 30. and also narrated by Ahmad bin Ali bin Syuaib an-Nasa'i, Sunan anNasa', Kitab; Salat Malam, Bab; Pertentangan diantara Aisyah tentang Salat Malam, (1 ${ }^{\text {st }}$ Printing; Riyad, Maktabah alMa'arif, T.Th), p. 270. and Muhammad bin yazid al-Qazwiny Ibnu Majah, Sunan Ibnu Mâjah, Kitab; Zubud, Bab; Konsisten Dalam Beramal, (1 ${ }^{\text {st }}$ printing; Riyad, Maktabah al-Ma'arif, T.Th), p. 702
} 
This hadith shows that the Prophet Muhammad did not praise the practices carried out by the woman, about the night prayers that made him not sleep at night only intended to do it. It was shown when the Prophet Muhammad told 'Aisha to stop the woman's story because the practice he carried out was not worthy of praise because it contains an element of imposing themselves in carrying out the teachings of Islam. While Islam forbids forcing yourself. ${ }^{23}$

This information shows that even in religion contained values of tolerance, convenience, friendliness, and respect that are in line with its universality so that it becomes a religion that is relevant in every place and time for every group of people and humanity. There are many Qur'anic verses explain that Islam is a religion loaded with ease including the word of God:

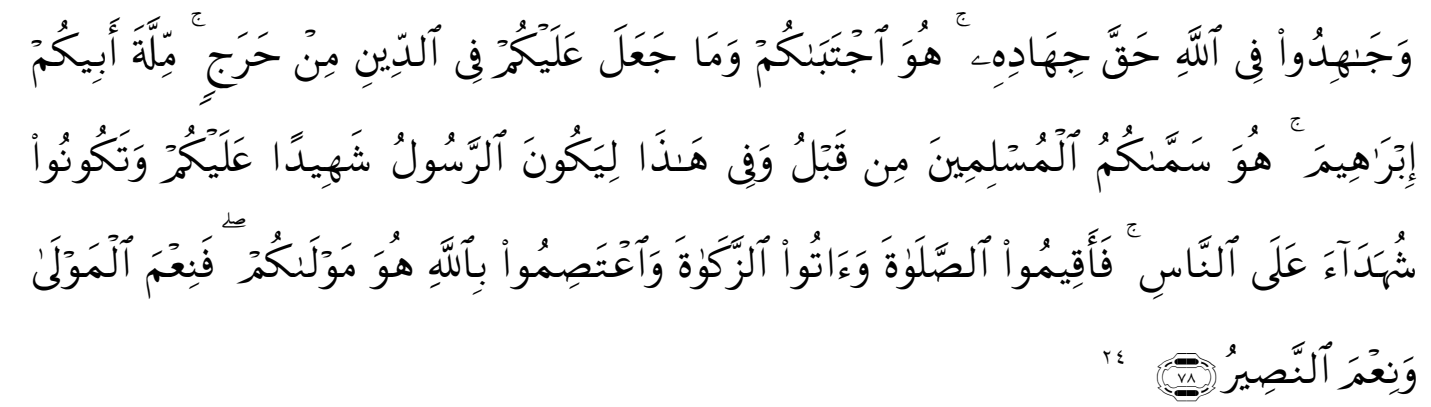

In another verse Allah says:

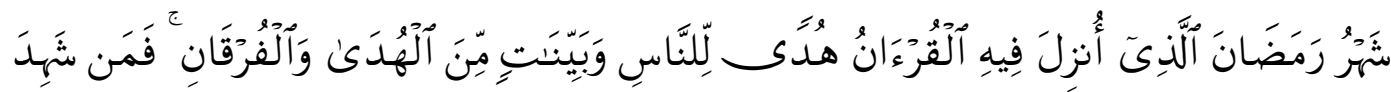

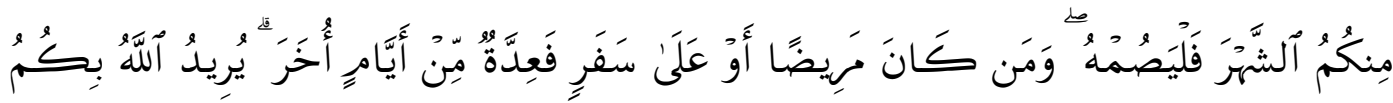

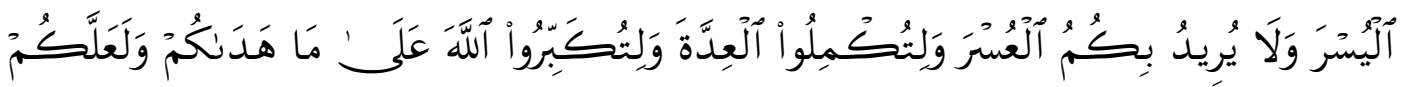

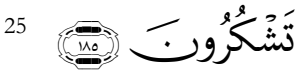

And in Muslim history, the Prophet Muhammad said:

${ }^{23} \mathrm{Al}-{ }^{-A}$ Asqalany, Op.Cit., Vol. I, p. 164

${ }^{24} \mathrm{Q} . \mathrm{S}$ al-Hajj: 78

${ }^{25}$ Q.S al-Baqarah: 185 
Millatī, Journal of Islamic Studies and Humanities, Vol. 4, No. 2, Desember 2019: 208-227

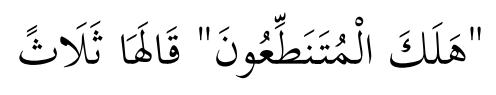

"Losses for those who exceed the limits are repeated three times". ${ }^{26}$

The word: "al-mutanatiun" are people who exaggerate and exceed the limits in explaining and practicing religious teachings, ${ }^{27}$ al-Qadi 'Iyad said the purpose of their loss was in the hereafter. ${ }^{28}$ In this hadith, a warning appears to avoid the harsh and excessive nature of carrying out religious teachings. ${ }^{29}$

Tolerance in Islam does not mean syncretic which means that tolerance must be related to sharia laws and errors in understanding the meaning of at-tasâmuh which means respect can result in mixing between the right and the vanity (talbisu al-haq bi al-bâtil), because of the attitude syncretism is an attitude that considers all religions to be the same while an attitude of tolerance in Islam is an attitude of respecting and respecting beliefs and other religions outside of Islam not equating or equating with the Islamic faith itself.

The attitude of tolerance in Islam that is related to the creed is very clear that is when Allah ordered the Prophet Muhammad to invite the People of the Book to only worship God and not associate Him, Allah said:

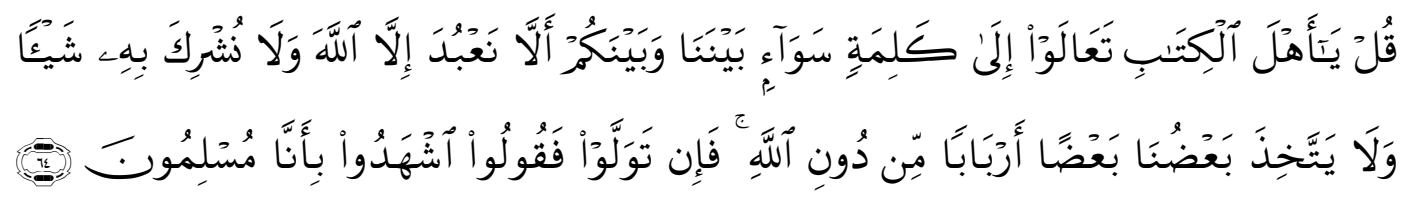

In this verse there is an order to invite the experts of the book of Jews and Christians to worship a single God and not deify humans without coercion and violence because in Islamic da'wah does not recognize the compulsion to believe as God says:

\footnotetext{
${ }^{26}$ Muslim bin Hajjaj bin Muslim al-Qusyairy an-Nisabury, al-Musnad al-Sabih, in Shafiyurrahman alMubarakfury, Minnat al-Mun'im Syarh Sabih Muslim, (1 ${ }^{\text {st }}$ Printing; Riyad: Dar as-Salam, 1420 H / 1999 M), Vol. IV, p. 228

${ }^{27}$ Ibid.,

${ }^{28}$ Iyadh bin Musa bin Iyadh, Ikamal al-Mu'allim bi Fawaid Muslim, (1 ${ }^{\text {st }}$ Printing; al-Manshura: Dar al-Wafa, 1419 H / 1998 M), Vol VIII, p. 164

${ }^{29}$ Musa Syahin al-Asyin, Fath al-Mun'im Syarh Shabih Muslim, (Cet. I; Kairo: Dar al-Syuruq, 1423 H / 2002 M), Vol. X, p. 164

${ }^{30}$ Q.S Ali Imran: 64
} 
"There is no compulsion in religion (Islam)", 31

In some narrations it is known that the Prophet Muhammad never said harshly to his enemies. Even he hoped that Allah would give them guidance to believe. Among these narrations is the story of the Daus tribe which rejects the Islamic da'wah delivered by Tufail bin Amr ad-Dausi then to this matter to the Messenger of Allah. then he prayed:

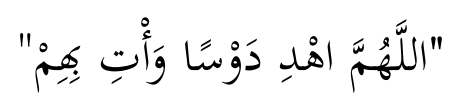

"O Allah, Point the Daus tribe a guidance and give it to them" ${ }^{32}$

Based on the history above, there is no doubt that in fact the Prophet Muhammad was sent to be a mercy for all nature. He likes to see humans in peace. He doesn't like destruction. He wants all humans to live happily. As for those who have reached their call to do good, but still don't like peace, they need to be opposed. ${ }^{33}$

The attitude of the Prophet Muhammad who craved peace he expressed:

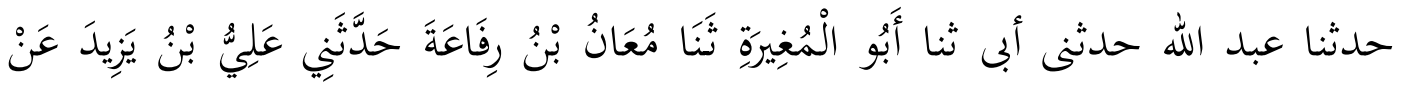

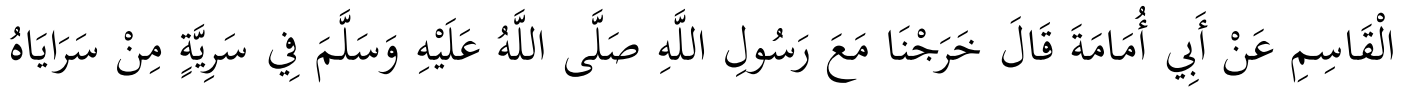

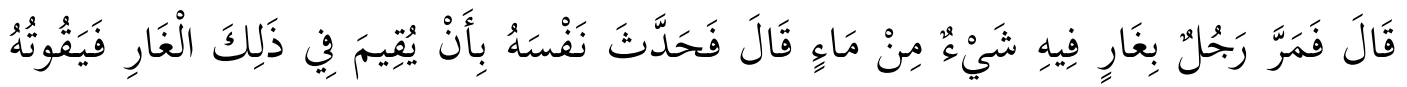

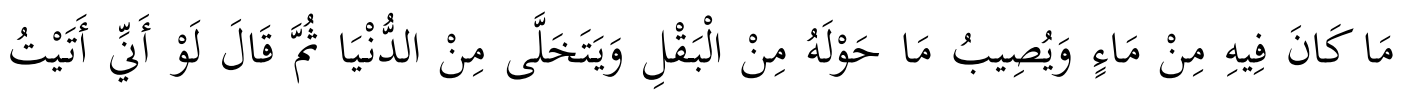

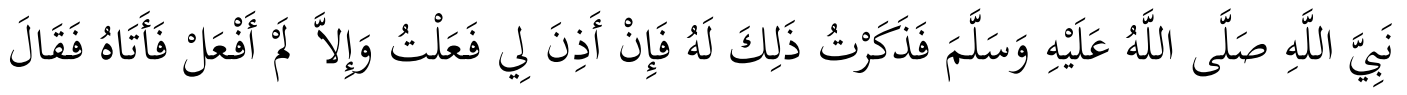

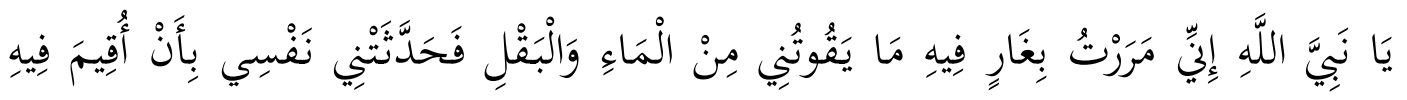

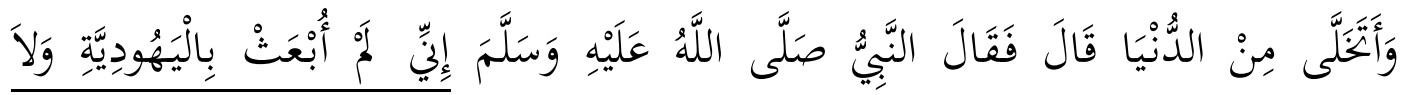

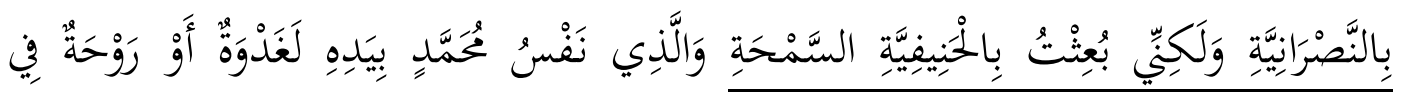

${ }^{31}$ Q.S Al-Baqarah : 256

${ }^{32}$ Al-Bukhari, Op.Cit., Book; Jihad, bab; Do'a Bagi Orang-orang Musyrik, Vol. II, p. 341. and Moslem, Op.Cit., in al-Mubarakfury., Op. Cit., Vol. IV, p. 154

${ }^{33} \mathrm{Abu}$ Muhammad Mahmud bin Ahmad al-Ainy, 'Umdat al-Qary, Syarh Shabih al-Bukehari, (1 ${ }^{\text {st }}$ Printing; Beirut: Muassasah ar-Risalah, 1421 H / 2001 M), Vol. XIV, p.291 
Millatī, Journal of Islamic Studies and Humanities, Vol. 4, No. 2, Desember 2019: 208-227

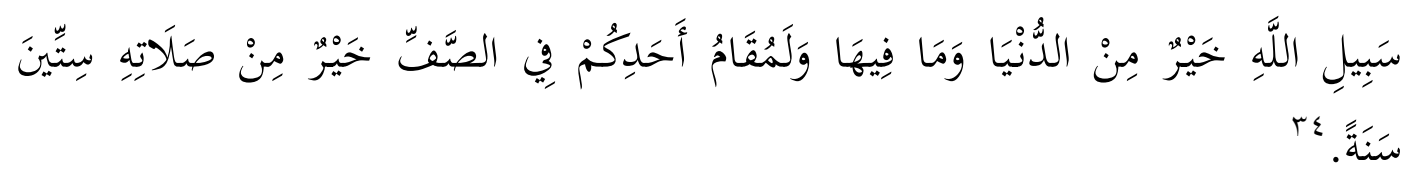

\section{Foundations of Tolerance in the Hadith}

Tolerance in the traditions leads to openness and willingness to acknowledge various kinds of differences. Those differences are differences between ethnicity, skin color, language, customs, culture, language and religion. Difference is the nature of God's decrees. This basic rationale is strengthened by the word of God in the QS. Al-Hujurat verse 13:

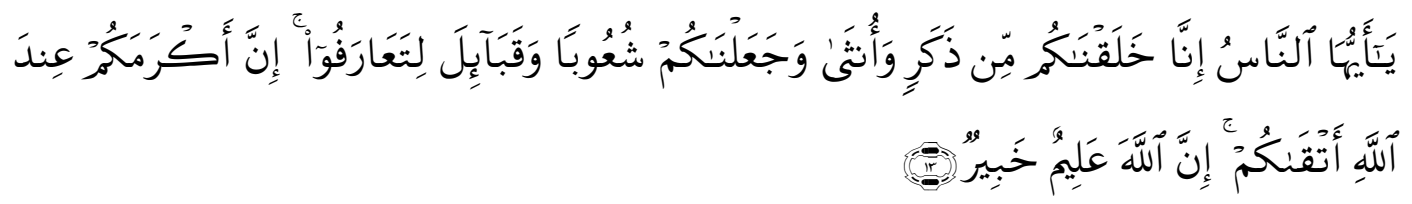

All humans will not be able to reject God's rules. Thus, for humans, it is proper to follow God's instructions in dealing with these differences. Tolerance among different religious communities is included in one of the important studies that exist in the Islamic theological system. Because God always reminds us to realize that differences are real. Humans differ in religion, ethnicity, skin color, customs, culture and so on.

Tolerance in religion does not mean that we today may be free to adhere to a certain religion and tomorrow we adhere to another religion or freely follow the worship and ritualism of all religions without binding rules. But religious tolerance is to realize that each religion is different and the worship of each religion is different.

The concept of tolerance offered by the hadith is very rational and practical. But that does not mean that everyone is justified to leave one religion and then enter another religion. Everyone who has faith must be consistent with his religion. Every need must have a strong foundation. Every religion does not allow to underestimate the beliefs of others. So the word tasâmuh or tolerance in Islam has been applied in life since the religion emerged.

\footnotetext{
${ }^{34}$ Imam Ahmad bin Muhamad bin Hanbal bin Hilal bin Asad bin Idris bin Abdullah bin Hayyan bin Abdullah bin Anas bin 'Auf bin Qasithi bin Marin bin Syaiban bin Dzuhl bin Tsa'labah bin Uqbah bin Sha'ab bin Ali bin Bakar bin Wail, Musnad al-Imam Ahmad bin Hanbal, Juz 2, (Beirut: Dar al-Fikr, tt), p. 266 and declared by Al-Albani as hasan hadith, see Muhammad Nasiruddin al-Albany, Shabih ....op.cit., p. 122
} 
In this context it must be emphasized the hadith narrated by al-Bukhari that the Prophet Muhammad was asked about the religion most loved by Allah and he answered: alHanifiyyah as-Samhah (a straight religion that is full of tolerance). If you accept Islam as a tolerant religion, it means that Islam is a true religion.

\section{Tolerance and Muslim Unity}

Allah says in QS. Al-Hujurat verse 10:

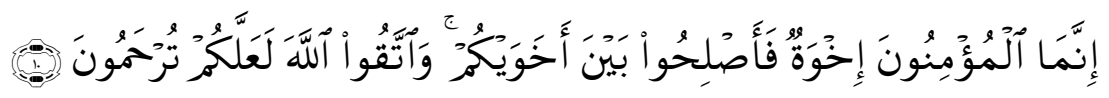

In the above verse, Allah states that believers are brothers and commands to do islah (improvement of relations) if there is a misunderstanding between 2 people or two groups. The Qur'an gives examples of the causes of relationship breakdown while banning any Muslim from doing so.

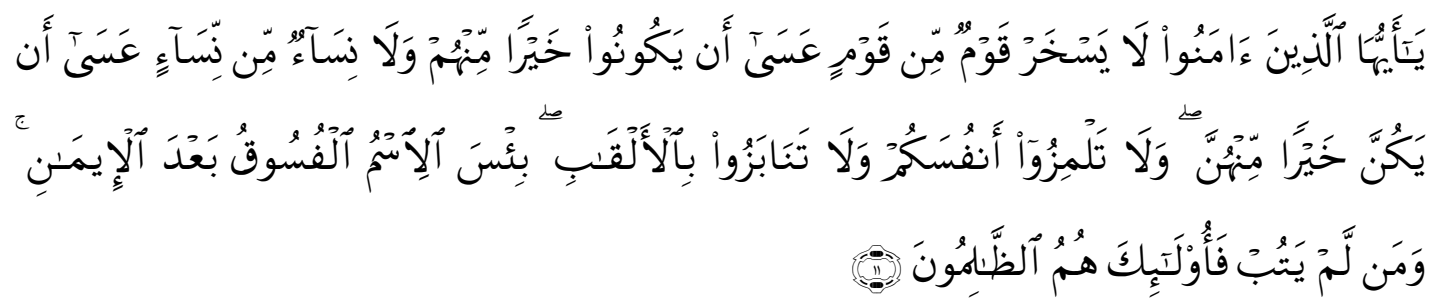

The above verse also instructs believers to avoid prejudice, not to find fault with others and to gossip like the Qur'an like eating the flesh of a deceased brother (QS.Al-Hujurat: 12)

To develop an attitude of tolerance in general, it can be started with how the ability to manage and respond to differences of opinion that might occur in the family. Tolerance begins with building togetherness or harmony and being aware of differences and being aware of all human brothers and sisters. In this way love, understanding, sympathy and tolerance will emerge. In the context of religious opinions and practices, the Qur'an explicitly commands believers to return to Allah (the Qur'an) and the Rasul (sunnah). ${ }^{35}$ If there is a difference in understanding the Qur'an and the hadith, whether resulting in differences in practice or not, then the instructions of the Qur'an are:

35 Dr. M. Quraish Shihab, Wawasan Alquran: Tafsir Maudh'i atas Pelbagai Persoalan Umat, Mizan, Bandung, 2003, p. 65 


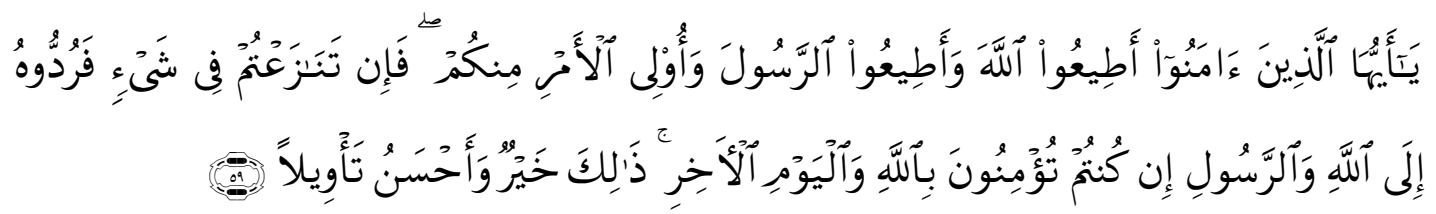

"O you who have believed, obey Allah and obey the Messenger and those in authority among you. And if you disagree over anything, refer it to Allah and the Messenger, if you should believe in Allah and the Last Day. That is the best [way] and best in result."

After Allah and the Apostle, what must be followed is ulil amri. When there is a difference in understanding the Qur'an and the hadith, then what must be considered is the view of people who are experts in the field or context that is being debated.

\section{Tolerance and Interfaith Business Relations}

In relation to tolerance between religious communities, tolerance should be interpreted as an attitude to be able to live together with people of other faiths by having the freedom to practice the principles of each religion. There should be no coercion and pressure in all contexts. Thus, at the level of social practices, it can be started from neighbors, because the most essential tolerance is the attitude of togetherness between religious adherents in social practices, neighborly and social life, and not just at the level of logic. and discourse. ${ }^{36}$

Tolerance among religious people can be started from living in a neighbor's life with neighbors who believe in us or not. This tolerance is reflected in mutual respect, mutual glory and mutual assistance. This was exemplified by the Prophet Muhammad when he and his companions were gathering, passing a group of Jews who were delivering the body. Prophet Muhammad stood to pay his respects. A friend said: "Aren't they Jews?" He replied, "Yes, but they are human too". So it is clear, that the aqeedah or theology is not a human affair, but God's business. Equally equal is humanity humanity.

Regarding different belief systems and religions, the Qur'an explains in the last verse of Surah Al-Kafirun: 6.

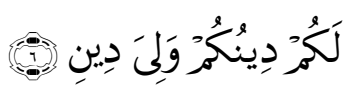

"For you your religion, for me my religion"

\footnotetext{
${ }^{36}$ Casram, "Membangun Sikap Toleransi Beragama Dalam Masyarakat Plural", Wawasan: Jurnal Ilmiah Agama dan Sosial Budaya, vol. 1, no. 2 (2016), p.187-198.
} 
That the principle of adhering to a single religion is a necessity. It is impossible for humans to adhere to several religions at the same time and it is impossible to practice the teachings of various religions simultaneously. Therefore, the Qur'an emphasizes that Muslims hold fast to the One God. God explains about the principle that every religion has its own system and teachings so there is no need to blaspheme each other. "Say:" Each person does according to his own circumstances. " (Surah Al Isra ': 84); "You are free from what I do and I will be free from what you do." (Surah Yunus: 41); "For us our deeds and to you your deeds." (Surah Al Qashshash: 55)

That is how Allah commands respect for each other in religious differences. In the affairs of life, all must work together to achieve justice, equality and human well-being. While for the afterlife, guidance and guidance is the absolute right of God. It is not appropriate to impose will on others.

Islam also recommends finding common ground and points of contact between adherents of religion. Islam recommends that in social interactions, if no equality is found, each should acknowledge the existence of the other party and not have to blame each other.

The Qur'an teaches the Messenger of Allah. and the ummah to convey to the followers of other religions after the sentence sawa '(meeting point) has not been reached (QS. Saba: 2426):

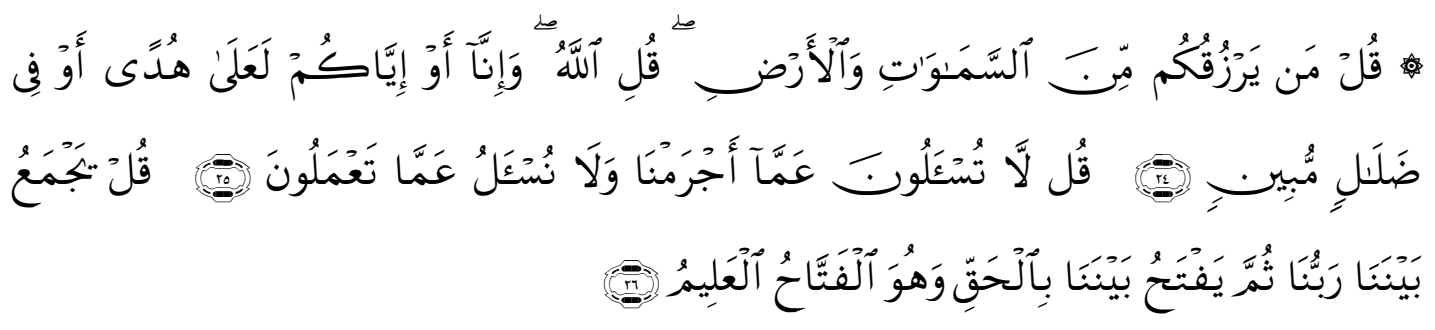

"Say, Who gave you sustenance from heaven and from earth? Say, Allah, and surely we or you (polytheists) must be in the truth or in real regret. Say, You will not be asked (responsible) about the sins we have committed and we will not be asked (also ) about what you do. Say, Our Lord will gather us all, then He will make the decisions between us correctly. as His allies, it is absolutely impossible! In fact, He is the All-Powerful, All-Wise God." 
Millatī, Journal of Islamic Studies and Humanities, Vol. 4, No. 2, Desember 2019: 208-227

\section{Religion for Good}

Each religion has a different doctrine. Doctrines arise from the construction of religion through an understanding authority that is believed to understand religion well. The construction of various religions is different. But it actually has the same basic foundation, which is the order to do good and the prohibition to do bad $^{37}$.

In Islam, anyone who makes it difficult for others, then Allah will complicate himself in the hereafter. Conversely anyone who makes it easier for others then God will give it ease. Islam is a religion of goodness. So that all goodness, no matter how simple it is, must be practiced, even though they only meet friends with cheerful faces. Every person, when given the opportunity to do good, then he must do good before the opportunity leaves. Every person is required to do good because the good doers are few even though the kind of good that can be done that much $^{38}$.

Having a professional opportunity dedicated to meeting the needs of many people is a great fortune. Because in fact he is God's chosen person. Such people are safe from the punishment of God. In this case, the profession as a teacher is a great fortune. In such a profession, when the contents of the teaching are motivations to do good, when the students do good, then for the teacher the reward is the same as doing good itself. Because "one who gives instructions to good, the reward is the same as doing good"39.

All of that goodness comes from God. Because that goodness that is received from someone is actually a kindness from God. Giving that kindness is only an intermediary. Therefore, excessive saying "may Allah reward you with kindness, jazakallahu khairan", is excessive gratitude. In Aceh, if someone gets good from someone, it says "Alhamdulillah". And what is even more dangerous is those who try to make themselves appear good. "The people who are most severely tortured on the Day of Judgment are those who are imaged of kindness when in fact there is no good at all.

Somehow the scheme arranged by God, which is clear, a hadith narrated by Abuzar asserted that if people do not do good and do not prevent evil, then they will be given a bad

${ }^{37}$ Mukti Ali, "Hubungan Antar Agama dan Masalah-Masalahnya" dalam Konteks Berteologi di Indonesia, (Jakarta: BPK Gunung Mulia, 1994), p. 127.

${ }^{38}$ Muhammad Faiz Almath, 1100 Hadits Terpilib Sinar Ajaran Mubammad, Jakarta: Gema Insani Press, 2004),p. 112-113.

${ }^{39}$ Ibid,h. 114 
leader and the prayers of good people among them are not granted ${ }^{40}$. The command to call for good and prevent evil is attributed to people of all religions. Even the call for virtue to the ruler who wronged his virtues was the same as jihad ${ }^{41}$.

Everyone is instructed by God to prevent munkar according to his ability, starting with his hands, mouth and heart. A person is thrown into hell when he calls for good and prevents munkar but he himself does not. Understanding of good and bad can be understood by anyone who understands. lay people and experts also see the ugliness but do not have any effort to prevent it, then it is hated by God.

"Let people give each other fortune ${ }^{42 "}$. This hadith shows how happy God is to the people who share, give to each other. When God wants progress and prosperity to a society, then He makes it easy for brands to buy and sell. But if He wants traffic and failure for them, then He opens the door betrayal. This shows how God regulates the welfare of the community through his social services and makes a society insulted by the betrayals in it.

Social tolerance and benefit are realized by avoiding jealousy, not bringing up each other badness, not hating each other and being hostile, not offering higher than other people's twins, not being wrong, not being arrogant, not looking down on others and not looking down on others' honor.

A rotten heart is the root of social decay. Al-Faqih Abu Laits Samarqandi explained that the diseases of the heart were not fulfilling other people's rights, not like silaturrahmi, drinking wine or the like, lying, gossiping, lambs singing, jealous of envy, arrogant, arrogant basic needs, laughing out loud, angry, don't keep verbal, greedy, love the world and don't have patience $^{43}$.

\section{CONCLUSION}

Terminology of Al-hanifiyyah as-samhah as stipulated in the Prophet's hadith: ababbu ad-dîn ${ }^{44}$ ila Allâh al-hanifiyyah as-sambah (the most loved religion by Allah is al-hanifizyah al-sambah: religion oriented to the spirit to seek truth in a tolerant and roomy manner). Here, the meaning of as-

\footnotetext{
${ }^{40}$ Ibid,h. 116.

${ }^{41}$ Muhammad Fuad Abdul Baqi, Shabih Bukhari-Muslim, (Jakarta: Gramedia, 2017).

42Almath, 1100 Hadits, p. 193.

${ }^{43}$ Al-Faqih Abu Laits Samarqandi, Tanbibul Ghofilin (Surabaya: Mutiara Ilmu, 2009).

${ }^{44}$ Ahmad Gaus AF, Api Islam Nurcholish Madjid: Jalan Hidup Seorang Visioner, (Jakarta: Kompas, 2010), p.
} 353. 
Millatī, Journal of Islamic Studies and Humanities, Vol. 4, No. 2, Desember 2019: 208-227

samhah, contains linguistic affinity with tasâmuh or samâha: a modern Arabic terminology to refer to tolerance. The Prophet's hadith is often used as a reference for Islam to support tolerance of other religions.

Nurcholish Madjid likes to use the terminology of Al-hanifiyyah as-samhah; not only as one of the main keys to explain the importance of tolerance in the Islamic prophetic tradition, but also interpreted as our attitude to always seek the truth tolerantly. It is not justified to do absolutism in the search for truth ${ }^{45}$. No attitude of truth can be obtained absolutely while closing the door tightly to the possibility of another party to find the truth. This not only contradicts the message of the Prophet Muhammad to be tolerant in any attempt to find the truth, but also the attitude of absolutism as it leads us to the attitude of self-worship, which is referred to in Islam by the term taghut.

Self-idolatry which closes us from the truth. The meaning of tolerance in Islam should always be accompanied by an attitude of humility and grace, while continuing to be open to acknowledge the possibility of others being right. Tolerance is the path to inclusivisness: selfdisclosure to see the possibility of other people's opinions right, and the possibility of our opinions are wrong. This awareness is a form of mind and heart awareness, which can be achieved through a harmonious blend of rational maturity, self-wisdom and wisdom of the heart. This is truly inclusive tolerance, which is one of the basic foundations of modern democracy. Therefore, the Prophet's achievements in the Medina period were judged Robert $\mathrm{N}$. Bellah as a modern achievement because it upholds the principles of tolerance and egalitarianism ${ }^{46}$.

Tolerance is the attitude of providing convenience, grace, silence, and respect as defined by experts in both English and Arabic lexicographers. Islam is a religion that makes tolerance the most important part, this attitude is more applied in the area of social interaction as shown from the attitude of the Prophet. against non-Muslims when he was still alive. The attitude of tolerance in religion is to respect the beliefs of other religions by not being syncretistic, namely by equating the beliefs of other religions with the beliefs of Islam itself.

${ }^{45}$ Miswari, Islam Maz̧hab Tutup Botol, (Lhokseumawe: 2018), p. 5-6.

${ }^{46}$ Robert N. Bellah, Religion in Human Evolution, (Harvard: Harvard University Press, 2011). 
Arguments of Hadith for Tolerance..... (Ismail Fahmi Arrauf Nasution and Miswari)

\section{REFERENCES}

al-'Asqalany, Ahmad bin Ali bin Hajar,Fath al-Barî, vol. I, Madinah al-Munawarah, 1996.

al-Ainy, Abu Muhammad Mahmud bin Ahmad, 'Umdat al-Qary, Syarh Shahih al-Bukhary. $1^{\text {st }}$

Printing, Beirut: Muassasah ar-Risalaah, 2001.

al-Ainy, Abu Muhammad Mahmud bin Ahmad,'Umdat al-Qary, Syarh Shahih al-Bukhari, $1^{\text {st }}$

printing, Vol. XIV, Beirut: Muassasah ar-Risalah, 1421 H / 2001 M.

al-Albany, Muhammad Nasiruddin, Shabih Adab al-Mufrad. 2 ${ }^{\text {nd }}$ Printing; Beirut: Dar ashShiddiq, 1415.

al-Asqalany, Ahamd bin Ali bin Hajar, Fath al-Bary, 1st Printing; Madinah al-Munawarah, 1996.

al-Asyin, Musa Syahin, Fath al-Mun'im Syarh Shahih Muslim. $1^{\text {st }}$ Printing; Kairo: Dar al-Syuruq, $1423 \mathrm{H} / 2002 \mathrm{M}$.

al-Atsir, Mujiddudin Ibnu, al-Nihayah fii Gharib al-Hadis. $1^{\text {st }}$ Printing, Vol. II, Lahore: Dar Anshar as-Sunnah, T.Th.

al-Bukhary, Muhammad bin Ismail bin Ibrahim, al-Jami' al-Shahih. $1^{\text {st }}$ Printing; Kairo: Maktah as-Salafiyah, $1400 \mathrm{H}$.

Ali, Mukti, "Hubungan Antar Agama dan Masalah-Masalahnya" in Konteks Berteologi di Indonesia, Jakarta: BPK Gunung Mulia, 1994.

al-Ju'fiy, Imam Abi Abdillah Muhammad bin Ismail bin Ibrahim ibn al-Mughirah bin

Bardazibah al-Bukhariy Shahih al-Bukhari, Juz 1, Semarang: Maktabah wa Matba'ah Usaha Keluarga, 198.1

al-Mandzur, Jamaluddin Muhammad bin Mukram Ibn, Lisân al-'Arab, $1^{\text {st }}$ Printing, Vol. 7 Beirut: Dar Shadir., 1993.

Almath, Muhammad Faiz 1100 Hadits Terpilih Sinar Ajaran Muhammad, Jakarta: Gema Insani Press, 2004.

al-Mubarakfury, Shafiyurrahman, Minnat al-Mun'im Syarb Shabih Muslim. $1^{\text {st }}$ Printing; Riyadh: Dar as-Salam, 1420 H / 1999 M.

Al-Naysaburi, Abi al-Hasan Ali bin Ahmad al-Wahidi. Asbab al-Nuqul. Jakarta: Dinamika Barakah Utama, t.th.

al-Qaradhawi, Yusuf, Fatâwâ Mu'âshirah. ${ }^{\text {rd }}$ Printing, Vol. 2. Mansurah: Dar al-Wafa'. 1994.

Al-Sijistaniy, Abu Sawud Sulaiman Muhammad bin al-Asyats.Sunan Abu Dawud, juz III.Indonesia: Makbatah Dahlan, t.th. 
Millatī, Journal of Islamic Studies and Humanities, Vol. 4, No. 2, Desember 2019: 208-227

Al-Suyuti, Jalal al-Din.al-Durru al-Mantsur fi al-Tafsir al-Ma'tsur, juz II. Bairut: Dar al-Maktab alIlmiah, $1411 \mathrm{H} / 1990 \mathrm{M}$.

an-Nasa'i, Ahmad bin Ali bin Syuaib,Sunan an-Nasa', Kitab; Salat Malam, Bab; Pertentangan diantara Aisyah tentang Salat Malam, ${ }^{\text {st }}$ Printing; Riyad, Maktabah al-Ma'arif, T.Th.

an-Nasa'i, Ahmad bin Ali bin Syuaib, Sunan an-Nasa'i. $1^{\text {st }}$ Printing; Riyadh, Maktabah al-Ma'arif, T.Th.

An-Nawawi, Imam Terjemah Lengkap Riyadish Shalibin, Surakarta: Ziyad Books, 2017.

an-Nisabury, Muslim bin Hajjaj bin Muslim al-Qusyairy al-Musnad al-Sahih, dalam Shafiyurrahman al-Mubarakfury, Minnat al-Mun'im Syarb Sabih Muslim, 1 ${ }^{\text {st }}$ Printing; Riyad: Dar as-Salam, 1420 H / 1999 M.

Bellah, Robert N., Religion in Human Evolution, Harvard: Harvard University Press, 2011.

Casram, "Membangun Sikap Toleransi Beragama Dalam Masyarakat Plural”, Wawasan: Jurnal Ilmiah Agama dan Sosial Budaya, vol. 1, no. 22016

Cici Kusnadi, “Kajian Al-Qur'an Dan Sunnah Tentang Toleransi”, Al-Karimah Jurnal Ilmiah Ilmu Tarbiyah Dan Ekonomi Syariah, Vol. 04 No. 07, 2017.

Gama, Cipta Bakti, "Fondasi Psikopatologi Islam: Suatu Pendekatan Psikofilosofis tentang Konsep Gangguan Jiwa dan Faktor Penyebabnya dalam Alquran”, Dissertation, PTIQ Jakarta, 2018.

Gaus, AF Ahmad, Api Islam Nurcholish Madjid: Jalan Hidup Seorang Visioner, Jakarta: Kompas, 2010.

Hornby. A. S., Oxford Advanced Learners Dictionary of Current English. 23 ${ }^{\text {rd }}$ Printing. London: Oxford University Press. 1986.

Ibn Iyadh, Iyadh bin Musa, Ikamal al-Mu'allim bi Fawaid Muslim. $1^{\text {st }}$ Printing; al-Manshura: Dar al-Wafa, 1419 H / 1998 M.

Ibnu Majah, Muhammad bin Yazid al-Qazwiny, Sunan Ibnu Majah. $1^{\text {st }}$ Printing; Riyadh, Makatah al-Ma'arif, T.Th.

Iyadh, Iyadh bin Musa bin,Ikamal al-Mu'allim bi Fawaid Muslim, $1^{\text {st }}$ Printing, Vol. VIII alManshura: Dar al-Wafa, 1419 H / 1998 M.

Majah, Muhammad bin yazid al-Qazwiny Ibnu, Sunan Ibnu Mâjah, Kitab; Zubud, Bab; Konsisten Dalam Beramal, ${ }^{\text {st }}$ Printing; Riyad, Maktabah al-Ma'arif, T.Th 
Arguments of Hadith for Tolerance..... (Ismail Fahmi Arrauf Nasution and Miswari)

Ministry of Education and Culture of the Republic of Indonesia, Kamus Besar Bahasa Indonesia. $2^{\text {nd }}$ Edition.1st Prinitng, Jakarta: Balai Pustaka, 1991.

Miswari, Islam Mą̧ab Tutup Botol, Lhokseumawe: 2018.

Munawwir, Ahmad Warson, Kamus al-Munawwir Arab Indonesia Terlengkap, $2^{\text {nd }}$ Edition. $14^{\text {th }}$ Printing. Surabaya: Pustaka Progresif, 1997.

Nasution, Ismail Fahmi Arrauf Melarai Titik Tengkar Agama: Teologi Dialog Antaragama dalam Alquran, Langsa: Zawiyah, 2015.

Noorhidayati, Salamah, "Hubungan Antar Umat Beragama Dalam Perpektif Hadits", Kalam. Vol. 10, No. 2, 2016.

Salman, Abdul Malik, al-Tasâmuh Tijâh al-Aqaliyyât ka Darûratin li al-Nabdah. Kairo: The International Institute of Islamic Thought, $1415 \mathrm{H}$.

Samarqandi,Al-Faqih Abu Laits, Tanbibul Ghofilin Surabaya: Mutiara Ilmu, 2009.

Setiyawan, Agung, "Pendidikan Toleransi Dalam Hadits Nabi Saw", Jurnal Pendidikan Agama Islam, Vol. XII, No. 2, 2015.

Shihab, M. Quraish Wawasan Alquran: Tafsir Maudbu'i atas Pelbagai Persoalan Umat, Mizan, Bandung, 2003

Shihab, M. Quraish. Wawasan Alquran. Bandung: Mizan, 1996

Wahid, Ramli Abdul, Kamus Lengkap Ilmu Hadis. $1^{\text {st }}$ Printing; Medan, Perdana Publishing, 2011

Wail, Imam Ahmad bin Muhamad bin Hanbal bin Hilal bin Asad bin Idris bin Abdullah bin Hayyan bin Abdullah bin Anas bin 'Auf bin Qasithi bin Marin bin Syaiban bin Dzuhl bin Tsa'labah bin Uqbah bin Sha'ab bin Ali bin Bakar bin Musnad al-Imam Ahmad bin Hanbal, Juz 2, Beirut: Dar al-Fikr, tt. 